This is the peer reviewed version of the following article: Reyes-García, Victoria, et al. "The contributions of Indigenous Peoples and Local Communities to ecological restoration." Restoration Ecology., which has been published in final form at https://doi.org/10.1111/rec.12894. This article may be used for non-commercial purposes in accordance with Wiley Terms and Conditions for Use of Self-Archived Versions. 


\section{The contributions of Indigenous Peoples and Local Communities to ecological}

\section{restoration}

Running head: Indigenous Peoples for Ecological Restoration

Victoria Reyes-García ${ }^{\mathrm{a}, \mathrm{b}}$, Álvaro Fernández-Llamazares ${ }^{\mathrm{c}}$, Pamela McElwee ${ }^{\mathrm{d}}$, Zsolt Molnár ${ }^{\mathrm{e}}$, Kinga Öllerer ${ }^{\mathrm{e}, \mathrm{f}}$, Sarah Jane Wilson ${ }^{\mathrm{g}}$, Eduardo Brondizio ${ }^{\mathrm{h}}$

${ }^{a}$ Institució Catalana de Recerca i Estudis Avançats (ICREA), Barcelona, Spain

b Institut de Ciència i Tecnologia Ambientals (ICTA), Universitat Autònoma de Barcelona, 08193 Bellatera, Barcelona, Spain

${ }^{c}$ Global Change and Conservation (GCC), Helsinki Institute of Sustainability Science (HELSUS), Faculty of Biological and Environmental Sciences, University of Helsinki, Helsinki, Finland

${ }^{\mathrm{d}}$ Department of Human Ecology, Rutgers University, New Jersey, USA

${ }^{\mathrm{e}}$ MTA Centre for Ecological Research, GINOP Sustainable Ecosystems Group, 8237 Tihany, Hungary

${ }^{\mathrm{f}}$ Institute of Biology Bucharest, Romanian Academy, 060031 Bucharest, Romania

${ }^{\mathrm{g}}$ PARTNERS reforestation network, University of Connecticut, CT, USA

${ }^{\mathrm{h}}$ Department of Anthropology, Indiana University, Bloomington, USA

Corresponding author:

Victoria Reyes-García

ICREA Research Professor

Institute of Environmental Science and Technology (ICTA-UAB)

ICTA-ICP, Edifici Z

Carrer de les Columnes

Universitat Autònoma de Barcelona

E-08193, Bellaterra (Cerdanyola del Vallès-Barcelona)

Tel: +34 935868976

E-mail: Victoria.Reyes@uab.cat

Author contributions: VRG, EB conceived and designed the research; AFL, KÖ, PM, SJW, ZM conducted the literature review; all authors wrote and edited the manuscript.

\section{Abstract}

This article has been accepted for publication and undergone full peer review but has not been through the copyediting, typesetting, pagination and proofreading process, which may lead to differences between this version and the Version of Record. Please cite this article as doi: $10.1111 /$ rec. 12894 
Indigenous Peoples and Local Communities (IPLC) are affected by global environmental change because they directly rely on their immediate environment for meeting basic livelihood needs. Therefore, safeguarding and restoring ecosystem resilience is critical to support their wellbeing. Based on examples from the literature, we illustrate how IPLC participate in restoration activities maintaining traditional practices, restoring land degraded by outsiders, and joining outside groups seeking to restore ecosystems. Our review also provides examples of how Indigenous and local knowledge can be incorporated in the planning, execution, and monitoring of restoration activities. However, not all restoration initiatives engaging IPLC are beneficial or successful, and the factors that lead to success are not fully known. While local involvement in restoration projects is often mentioned as an element of success, this is primarily associated to projects that actively involve IPLC in co-designing restoration activities affecting their territories, ensure both short-term direct benefits to IPLC and long-term support of the maintenance of restored areas, and recognize IPLC local traditions and customary institutions. Based on these examples, we argue that IPLC should be a more important focus in any post-2020 CBD agenda on restoration.

Key words: Co-management; Cultural Keystone Species; Ecosystem Services; Indigenous and Local Knowledge (ILK); Traditional management. 


\section{Implications}

- Actively involving Indigenous Peoples and Local Communities (IPLC) in restoration efforts $\boldsymbol{i}$ ) can help in site and species selection for restoration, $i$ ) can increase local participation in the planning, execution, and monitoring of restoration activities, and iii) can provide historical information on ecosystem state and management.

- The contribution of IPLC and their knowledge systems to ecological restoration could be more successful if restoration initiatives $i$ ) recognized IPLC customary institutions, ii) were built on partnerships with IPLC from their design, and iii) ensure both short-term direct benefits to IPLC and long-term support of the maintenance of restored areas.

- IPLC should also be included in any post-2020 Convention on Biological Diversity agenda on restoration. 


\section{The contributions of Indigenous Peoples and Local Communities to ecological restoration}

Indigenous Peoples and Local Communities (IPLC), generally defined as ethnic groups who are descended from and identify with the original inhabitants of a given region, are affected by global environmental change because they often rely directly on their immediate environments and local natural resources for meeting basic livelihood needs (Angelsen et al. 2014; Pecl et al. 2017). Degradation of natural resources can negatively affect their food and health sovereignty and overall wellbeing (Golden et al. 2016; Pecl et al. 2017), therefore safeguarding and restoring ecosystem resilience is often critical to support IPLC's wellbeing (Sangha \& Russell-Smith 2017).

In line with previous scholarly work recognizing the values of indigenous and local knowledge for conservation and development (see Reyes-García 2015 for a review), some researchers have argued that IPLC can be more than recipients of restoration activities, playing an active role in restoring ecosystems (e.g., Shaffer 2010; Wangpakapattanawong et al. 2010; Babai \& Molnár 2014; Uprety et al. 2012). However, IPLC's contributions to restoration activities continue to be largely absent in national, regional, and global environmental policy fora (Wehi \& Lord 2017). For example, Aichi Target 15 of the Convention on Biological Diversity stipulates the goal to restore $15 \%$ of degraded ecosystems, but decisions on which areas to restore are mainly based on biological importance and restoration feasibility rather than on local concerns (e.g., Tobón et al. 2017).

In this Opinion Article, we argue for the need to increase the engagement of IPLC in ecological restoration pursuits. We substantiate this argument by illustrating $i$ ) ways in which IPLC are already participating in restoration activities; ii) ways in which Indigenous and Local Knowledge (ILK) has been incorporated in restoration activities; 
and iii) factors that reportedly lead to successful restoration outcomes and increased wellbeing for IPLC. Our examples come from a literature search on IPLC and restoration conducted in the Web of Science. Our search yielded 413 papers. After a review of abstracts, we retained 120 articles containing both case studies and more generalized treatment of IPLC issues for further detailed review to draw lessons from (See Appendix S1 for methodological details).

\section{IPLC's participation in restoration activities}

IPLC are particularly well positioned to contribute to restore and safeguard ecosystems because they have an intimate knowledge of their lands and resources and the dynamics affecting them (Wehi \& Lord 2017) and because they have a vested interest in restoring ecosystems from which they directly benefit (Shaffer 2010; Wangpakapattanawong et al. 2010; Babai \& Molnár 2014). Although the global percentage of restoration efforts involving IPLC is unknown, there is evidence that IPLC play an active role in restoring a wide range of ecosystems around the world (Storm \& Shebitz 2006; Nagendra 2007; Lyver et al. 2016). We identified three main ways in which IPLC participate in restoration activities: (1) maintaining traditional management and practices; (2) restoring land degraded by outsiders; and (3) joining outside groups seeking to restore ecosystems.

Researchers have documented instances when, through traditional practices, IPLC manage, adapt, and restore the land on which their livelihood depends, sometimes creating new types of highly biodiverse ecosystems (Posey 1985; Babai \& Molnár 2014; Comberti et al. 2015). Examples of traditional practices contributing to maintaining and restoring ecosystems include 1) anthropogenic burning purposively altering spatial and temporal aspects of habitat heterogeneity to create diversity (Shaffer 
2010; Welch et al. 2013; Trauernicht et al. 2015); 2) waste deposition practices resulting in soil carbon enrichment (Solomon et al. 2016); 3) rotational swidden cultivation systems able to maintain forest cover and plant diversity (Wangpakapattanawong et al. 2010; Singh et al. 2014); 4) interplanting useful plants in native forests thereby increasing forest diversity (Garibaldi \& Turner 2004; Ford \& Nigh 2015), and 5) scattering species-rich hayseed, and weeding and cleaning meadows to maintain grassland productivity and resilience (Babai \& Molnár 2014).

Second, IPLC have also engaged in activities to restore their own lands and waters after these areas had been overexploited or degraded by outsiders. For example, traditional fire regimes have been used to restore overgrown broad-crowned black oak tree stands in California (Long et al. 2003). Similarly, in Alaska, the Qawalangin Tribe received funding to restore coastlines affected by pollution (NOAA 2017). In Nepal, the devolvement of state forests into community control in the 1970s slowed deforestation and led many local communities to safeguard and restore communal forests and watersheds, as these activities increased local ecosystem services (Paudyal et al. 2015). Restoration efforts led by IPLC have also helped to stem the tide of landscape change caused by urbanization or encroachment (Horiuchi et al. 2011). In some cases, restoration efforts have resulted in a change in the local political context, creating a space for assertion of Indigenous spiritual and cultural values to be further reflected in their participation in restoration efforts (Fox et al. 2017).

Finally, IPLC have also contributed to restoration activities initiated by other stakeholders. On the one side, IPLC have been key participants in several country-scale forest restoration efforts in Asia, particularly China and Vietnam (e.g., Clement \& Amezaga 2009; He \& Lang 2015). However, these campaigns have not always successfully involved farmers or impacted afforestation outcomes given the lack of 
clarity of the policies designed at the central level (e.g., Clement \& Amezaga 2009) or the neglect of local interests (e.g., He \& Lang, 2015). On the other side, IPLC have also taken leadership roles in restoring forests (Paquette et al. 2009; Douterlungne et al. 2010), lakes and rivers (Coombes 2007; Fox et al. 2017), grasslands and drylands (Pellant et al. 2004; Stenseke 2009), mangroves and reefs (Selvam et al. 2003; Trialfhianty \& Suadi 2017), and wetlands (Selvam et al. 2003; Henwood et al. 2016). Many of these activities have successfully coupled the goals of ecological restoration and increasing participation of IPLC.

\section{Using ILK to inform restoration activities}

Some authors specifically working with IPLC and restoration have noticed that ILK has often been neglected in ecological restoration programs (e.g., Robertson et al. 2000; Mills 2003; Wehi \& Lord 2017), arguably because of what Murphy (2011) calls the "epistemological authority" of Western, objectivist thinking among restoration and conservation ecologists. For instance, traditional IPLC-prescribed burning regimes are often dismissed in policy circles (Welch et al. 2013; Mistry et al. 2016), despite increasing evidence that fire management can contribute to wildfire prevention, climate change mitigation, and landscape heterogeneity (Defossé et al. 2011; Russell-Smith et al. 2015). However, as in other areas of natural resource management (Mistry \& Berardi 2016; Díaz et al. 2018), examples exist where ILK has been applied to increase the effectiveness of restoration activities (e.g., Senos et al. 2006; Uprety et al. 2012; Wehi \& Lord 2017). Our review notes that ILK has been incorporated in restoration activities primarily in three stages: 1) planning of restoration; 2) execution of restoration; and 3) monitoring of restoration. 
First, ILK has been used to identify what species to use and which sites to focus on in restoration efforts. ILK can provide baseline ecosystem information on cultural keystone species, i.e., culturally salient species that shape people's identity (Garibaldi \& Turner 2004), or cultural keystone places, i.e., particular places that are critically important for the flow of ecosystem service and to people's lifeways (Cuerrier et al. 2015). To date, in the absence of ILK, many reforestation efforts have resulted in monocultures, compositionally simple mixed forests, or the use of non-native species (e.g., Hua et al. 2016). Reforestation efforts aiming to restore higher levels of biodiversity have thus turned to ILK for the selection of appropriate native species (Garibaldi \& Turner 2004; Wangpakapattanawong et al. 2010), or cultural keystone places (Uprety et al. 2012; Cuerrier et al. 2015; Lepofsky et al. 2017), both in terrestrial and marine environments (Comberti et al. 2015; Thornton et al. 2015). Moreover, given the current debate on how to define a reference state for global restoration (e.g., Kotiaho et al. 2016), ILK is being used to estimate natural baselines for species recovery and to inform restoration targets (Nabhan 2000; Eckert et al. 2018), as -despite the fact that IPLCs can be affected by the Shifting Baseline Syndrome (e.g., Fernández-Llamazares et al. 2015)- IPLC historical continuity in resource use and close cultural connection to their environments puts them on a privileged position to contribute to setting local reference states for restoration targets.

Second, ILK has been used to guide actual ecosystem restoration processes. IPLC often have a long-term experience creating ecosystems that support and enhance the provision of ecosystem services (Comberti et al. 2015); in some places, IPLC have a deep understanding of local successional and regeneration processes of the degraded land. Simulating traditional management systems can help promote or accelerate succession (Anderson \& Barbour 2003; Diemont \& Martin 2009; Douterlungne et al. 
2010). Other ILK-based land management practices (e.g., rotational farming, agroforestry, improved crop-fallow systems, hedgerows, grazing enclosures) have also effectively enhanced carbon sequestration, prevented environmental degradation, and combatted desertification (e.g., Wangpakapattanawong et al. 2010; Coughlan 2014; Salick et al. 2014). Emulating Indigenous and traditional land management practices has been a way to incorporate ILK for effective restoration in national parks (Anderson \& Barbour 2003; Kis et al. 2017; Varga et al. 2017), restoring plant and bird communities in Swedish oak-hazel woodlands (Hansson 2001), and alluvial meadows in Mongolia (Jamsran 2010). Using Indigenous fire regimes to recover native biodiversity and ecosystem functions has been another way of incorporating ILK in restoration pursuits (Marsden-Smedley \& Kirkpatrick 2000; Storm \& Shebitz 2006). Oral histories embedded in ILK have produced baseline information for watershed restoration and helped to develop collaborative management in restoration (Mustonen 2013).

Finally, ILK can be useful in designing and implementing restoration monitoring programs (Uprety et al. 2012). Many initiatives engaging IPLCs in community-based carbon monitoring are gaining prominence in the wake of efforts for REDD+ (Reduced Emissions from Degradation and Deforestation) (Danielsen et al. 2013; Brofeldt et al. 2014; Butt et al. 2015; Hartoyo et al. 2016; McCall et al. 2016), although it is currently unknown to what degree these local monitoring projects also make use of traditional ILK. Continuing species shifts due to climate change (Pecl et al. 2017) renders urgent the need to monitor and potentially relocate species and ecosystems for benefits to IPLCs, arguing for further incorporation of ILK in monitoring.

\section{Factors leading to successful and beneficial restoration projects with IPLC}


Much work remains to understand the factors that lead to ecologically successful restoration that also benefits IPLC. Local involvement in restoration projects is often mentioned as an element of success, although the literature shows that engaging IPLC in restoration activities does not always lead to ecosystem restoration nor to benefits for IPLC (e.g., Clement \& Amezaga 2009). Thus, despite some restoration projects showing the creation of diversified livelihoods or an increase in smallholder's income or access to natural resources (Xu et al. 2007; Brown et al. 2011), there are also other projects that have had minimal or negative impacts on IPLC wellbeing (Boyd et al. 2007; Reynolds 2012).

The cases examined suggest that top-down planned restoration conducted with low levels of local participation often result in conflicts over landscape visions between the organizations proposing restoration and local inhabitants, potentially undermining long-term restoration success because of the lack of public acceptance (Couix \& Gonzalo-Turpin 2015; Heldt et al. 2016). In the same line, projects that involve IPLC only for labor or providing land are economically unsustainable for them, namely because of high opportunity costs of land and labor and delayed and low benefits, and thus are often not locally accepted (Jindal et al. 2012; Aggarwal 2014). Moreover, these projects may mostly benefit households that are already economically better off (Glomsrød et al. 2011).

Alternatively, projects that actively involve IPLC in co-designing restoration activities affecting their territories are reported as successful in that they build partnerships (e.g., for co-management) and address value conflicts over resources (Davenport et al. 2010; Lyver et al. 2016; Fox et al. 2017). Several cases of community forestry, i.e., projects involving local communities in forest management, provide a 
useful model for restoring degraded forests and informing restoration efforts (Nagendra 2007; Paudyal et al. 2015).

We found examples of other principles that may improve the success of restoration projects. Some authors have argued that ensuring that restoration projects receive technical and financial support to maintain restored areas (Nguyen et al. 2017), and providing sufficient incentives including short-term (e.g., rapidly providing resources or ecosystem services locally perceived as scarce - Mustonen 2013; Brancalion et al. 2014) and long-term benefits (e.g., sustained employment or 'useful' tree species from restoration - Le et al. 2012; Nielsen-Pincus \& Moseley 2013; BenDor et al. 2015) can also help improve restoration project's success.

In a different vein, authors have also argued that including cultural elements, such as revitalizing local traditions or recognizing customary institutions, might promote the understanding of restoration efforts and therefore increase local participation (e.g., Long et al. 2003; Wehi \& Lord 2017; de Koning et al. 2011; Godden \& Cowell 2016). For example, the creation stories of the White Mountain Apache Tribe reveal the importance and functions of water bodies within the landscape. These cultural traditions can help communicate the foundations of river restoration efforts and thus ensure community support (Long et al. 2003). Similarly, results from a study of 42 reforestation programs in Africa show that the success of such programs largely rest upon the ability of local institutions to monitor, impose sanctions, and distribute benefits (Reynolds 2012), thus highligting the importance of costumary institutions for restoration efforts. Researchers have also argued that in contexts where resource degradation is linked to the loss of cultural values, cultural revitalization linked to restoration provides another incentive and base of support for community-based conservation (Lopez-Maldonado \& Berkes 2017). 


\section{Conclusion}

The literature on IPLC and restoration provides examples of IPLC's initiatives and active participation in ecosystem maintenance and restoration, as well as of successful ways in which ILK can be incorporated in restoration activities. While there is not a comprehensive explanation of which factors lead to ecologically successful restoration that also benefits IPLC, the literature provide valuable insights on how i) involving IPLC and their knowledge in co-designing restoration activities affecting their territories, ii) ensuring short-term direct benefits to IPLC and long-term support of the maintenance of restored areas, and iii) building in local cultural elements to promote the understanding of restoration efforts have substantially contributed to the local acceptance of restoration efforts throughout the world.

Thus one major proposal as an outcome of our review is that IPLC should be a more important focus in the current efforts to meet Aichi Target 15 of the Convention on Biological Diversity (CBD) on restoring $15 \%$ of globally degraded ecosystems. IPLC should also be included in any post-2020 CBD agenda on restoration.

\section{Acknowledgements}

KÖ and ZM thank the National Research, Development and Innovation Office (GINOP-2.3.2-15-2016-00019) project. SJW thanks the PARTNERS restoration network. AFLL was supported by the Academy of Finland (grant agreement nr. 311176) and the Kone Foundation. This work contributes to the "María de Maeztu Unit of Excellence" (MdM-2015-0552). The authors declare they have no conflict of interest.

\section{References}


Aggarwal A (2014) How sustainable are forestry clean development mechanism projects?-A review of the selected projects from India. Mitigation and Adaptation Strategies for Global Change 19:73-91

Anderson MK, Barbour MG (2003) Simulated indigenous management: A new model for ecological restoration in national parks. Ecological Restoration, 21: 269-277

Angelsen A, Jagger P, Babigumira R, Belcher B, Hogarth NJ, Bauch S, Boerner J, Smith-Hall C, Wunder S (2014) Environmental Income and Rural Livelihoods: A Global-Comparative Analysis. World Development 64:S12-S28

Babai D, Molnár Z (2014) Small-scale traditional management of highly species-rich grasslands in the Carpathians. Agriculture, Ecosystems \& Environment 182:123130

Bendor T, Lester TW, Livengood A, Davis A, Yonavjak L (2015) Estimating the Size and Impact of the Ecological Restoration Economy. Plos One 10:e0128339

Boyd E, May P, Chang M, Veiga FC (2007) Exploring socioeconomic impacts of forest based mitigation projects: Lessons from Brazil and Bolivia. Environmental Science \& Policy 10:419-433

Brancalion PHS, Cardozo IV, Camatta A, Aronson J, Rodrigues RR (2014) Cultural Ecosystem Services and Popular Perceptions of the Benefits of an Ecological Restoration Project in the Brazilian Atlantic Forest. Restoration Ecology 22:6571

Brofeldt S, Theilade I, Burgess ND, Danielsen F, Poulsen MK, Adrian T, Bang TN, et al. (2014) Community Monitoring of Carbon Stocks for REDD+: Does Accuracy and Cost Change over Time? Forests 5(8):1834-54. doi:10.3390/f5081834 
Brown DR, Dettmann P, Rinaudo T, Tefera H, Tofu A (2011) Poverty Alleviation and Environmental Restoration Using the Clean Development Mechanism: A Case Study from Humbo, Ethiopia. Environmental Management 48:322-333

Butt N, Epps K, Overman H, Iwamura T, Fragoso JMV (2015) Assessing Carbon Stocks Using Indigenous Peoples’ Field Measurements in Amazonian Guyana. Forest Ecology and Management 338: 191-99. doi:10.1016/j.foreco.2014.11.014 Clement F, Amezaga JM (2009) Afforestation and forestry land allocation in northern Vietnam: Analysing the gap between policy intentions and outcomes. Land Use Policy 26:458-470

Comberti C, Thornton TF, Wyllie De Echeverria V, Patterson T (2015) Ecosystem services or services to ecosystems? Valuing cultivation and reciprocal relationships between humans and ecosystems. Global Environmental Change 34:247-262

Coombes B (2007) Defending community? Indigeneity, self-determination and institutional ambivalence in the restoration of Lake Whakaki. Geoforum 38:6072

Coughlan MR (2014) Farmers, flames, and forests: Historical ecology of pastoral fire use and landscape change in the French Western Pyrenees, 1830-2011. Forest Ecology and Management 312:55-66

Couix N, Gonzalo-Turpin H (2015) Towards a land management approach to ecological restoration to encourage stakeholder participation. Land Use Policy 46:155-162

Cuerrier A, Turner NJ, Gomes TC, Garibaldi A, Downing A (2015) Cultural Keystone Places: Conservation and Restoration in Cultural Landscapes. Journal of Ethnobiology 35:427-448 
Danielsen F, Adrian T, Brofeldt S, van Noordwijk M, Poulsen MK, Rahayu S,

Rutishauser E, et al. (2013) Community Monitoring for REDD+: International

Promises and Field Realities. Ecology and Society 18(3): 41. doi:10.5751/ES-

05464-180341

Davenport MA, Bridges CA, Mangun JC, Carver AD, Williard KWJ, Jones EO (2010)

Building local community commitment to wetlands restoration: A case study of the cache river wetlands in Southern Illinois, USA. Environmental Management 45:711-722

De Koning F, Aguiñaga M, Bravo M, Chiu M, Lascano M, Lozada T, Suarez L (2011)

Bridging the gap between forest conservation and poverty alleviation: the

Ecuadorian Socio Bosque program. Environmental Science \& Policy 14:531-542

Defossé GE, Loguercio G, Oddi FJ, Molina JC, Kraus PD (2011) Potential CO2

emissions mitigation through forest prescribed burning: A case study in

Patagonia, Argentina. Forest Ecology and Management 261:2243-2254

Díaz S, Pascual U, Stenseke M, Martín-López B, Watson RT, Molnár Z, Hill R, Chan

KMA, Baste IA, Brauman KA, Polasky S, Church A, Lonsdale M, Larigauderie

A, Leadley PW, Van Oudenhoven APE, Van Der Plaat F, Schröter M, Lavorel

S, Aumeeruddy-Thomas Y, Bukvareva E, Davies K, Demissew S, Erpul G,

Failler P, Guerra CA, Hewitt CL, Keune H, Lindley S, Shirayama Y (2018)

Assessing nature's contributions to people. Science 359:270-272

Diemont SaW, Martin JF (2009) Lacandon Maya ecosystem management: sustainable design for subsistence and environmental restoration. Ecological Applications 19:254-266 
Douterlungne D, Levy-Tacher SI, Golicher DJ, Danobeytia FR (2010) Applying Indigenous Knowledge to the Restoration of Degraded Tropical Rain Forest Clearings Dominated by Bracken Fern. Restoration Ecology 18:322-329

Eckert LE, Ban NC, Frid A, McGreer M (2017) Diving back in time: Extending historical baselines for yelloweye rockfish with Indigenous Knowledge. Aquatic Conservation: Marine and Freshwater Ecosystems 28: 158-166.

Ford A, Nigh R. (2015) The Maya Forest Garden: Eight Millennia of Sustainable Cultivation of the Tropical Woodlands. . Left Coast Press., Berkeley

Fox CA, Reo NJ, Turner DA, Cook J, Dituri F, Fessell B, Jenkins J, Johnson A, Rakena TM, Riley C, Turner A, Williams J, Wilson M (2017) “The river is us; the river is in our veins": re-defining river restoration in three Indigenous communities. Sustainability Science 12:521-533

Garibaldi A, Turner N (2004) Cultural Keystone Species: Implications for Ecological Conservation and Restoration. Ecology and Society 9

Glomsrød S, Wei T, Liu G, Aune JB (2011) How well do tree plantations comply with the twin targets of the Clean Development Mechanism? - The case of tree plantations in Tanzania. Ecological Economics 70:1066-1074

Godden L, Cowell S (2016) Conservation planning and Indigenous governance in Australia's Indigenous Protected Areas. Restoration Ecology 24 (5):692-697 Golden CD, Allison EH, Cheung WW, Dey MM, Halpern BS, Mccauley DJ, Smith M, Vaitla B, Zeller D, Myers SS (2016) Nutrition: Fall in fish catch threatens human health. Nature 534:317-320

Hansson L (2001) Traditional management of forests: plant and bird community responses to alternative restoration of oak-hazel woodland in Sweden. Biodiversity \& Conservation 10:1865-1873 
Hartoyo APP, Siregar IZ, Supriyanto, Prasetyo LB, Thelaide I (2016). Biodiversity, Carbon Stocks and Community Monitoring in Traditional Agroforestry Practices: Preliminary Results from Two Investigated Villages in Berau, East Kalimantan. Procedia Environmental Sciences 33: 376-85.

doi:10.1016/j.proenv.2016.03.088

He J, Lang R (2015) Limits of State-Led Programs of Payment for Ecosystem Services: Field Evidence from the Sloping Land Conversion Program in Southwest China. Human Ecology 43:749-758

Heldt S, Budryte P, Ingensiep HW, Teichgräber B, Schneider U, Denecke M (2016) Social pitfalls for river restoration: How public participation uncovers problems with public acceptance. Environmental Earth Sciences 75:1053

Henwood W, Moewaka Barnes H, Brockbank T, Gregory W, Hooper K, Mccreanor T (2016) Ko Tāngonge Te Wai: Indigenous and Technical Data Come Together in Restoration Efforts. EcoHealth 13:623-632

Horiuchi M, Fukamachi K, Oku H (2011) Reed community restoration projects with citizen participation: an example of the practical use of Satoyama landscape resources in Shiga Prefecture, Japan. Landscape and Ecological Engineering 7:217-222

Hua F, Wang X, Zheng X, Fisher B, Wang L, Zhu J, Tang Y, Yu DW, Wilcove DS (2016) Opportunities for biodiversity gains under the world's largest reforestation programme. Nature Communications 7: 12717.

Jamsran U (2010) Involvement of Local Communities in Restoration of Ecosystem Services in Mongolian Rangeland. Global Environmental Research 14:79-86 
Jindal R, Kerr JM, Carter S (2012) Reducing Poverty Through Carbon Forestry? Impacts of the N'hambita Community Carbon Project in Mozambique. World Development 40:2123-2135

Kis J, Barta S, Elekes L, Engi L, Fegyer T, Kecskeméti J, Lajkó L, Szabó J (2017) Traditional herders' knowledge and worldview and their role in managing biodiversity and ecosystem services of extensive pastures. Pages 57-71 In: Roué M, Molnár Z, (eds) Knowing our Land and Resources: Indigenous and local knowledge of biodiversity and ecosystem services in Europe \& Central Asia. UNESCO, Paris

Kotiaho JS, ten Brink B, Harris J (2016) A global baseline for ecosystem recovery. Nature 532: 37.

Le HD, Smith C, Herbohn J, Harrison S (2012) More than just trees: Assessing reforestation success in tropical developing countries. Journal of Rural Studies 28:5-19

Lepofsky D, Armstrong CG, Greening S, Jackley J, Carpenter J, Guernsey B, Mathews D, Turner NJ (2017) Historical Ecology of Cultural Keystone Places of the Northwest Coast. American Anthropologist 119:448-463

Long J, Tecle A, Burnette B (2003) Cultural foundations for ecological restoration on the White Mountain Apache Reservation. Conservation Ecology 8:4

Lopez-Maldonado Y, Berkes F (2017) Restoring the environment, revitalizing the culture: cenote conservation in Yucatan, Mexico. Ecology and Society 22:7

Lyver POB, Akins A, Phipps H, Kahui V, Towns DR, Moller H (2016) Key biocultural values to guide restoration action and planning in New Zealand. Restoration Ecology 24:314-323 
Marsden-Smedley JB, Kirkpatrick JB (2000) Fire management in Tasmania's

Wilderness World Heritage Area: Ecosystem restoration using Indigenous-style fire regimes? Ecological Management \& Restoration 1:195-203

McCall MK, Chutz N, Skutsch M (2016) Moving from Measuring, Reporting,

Verification (MRV) of Forest Carbon to Community Mapping, Measuring, Monitoring (MMM): Perspectives from Mexico. PLoS ONE 11(6): e0146038. doi:10.1371/journal.pone.0146038

Mills M (2003) Restoring the Mauri of Oruarangi Creek. Water Sci Technol 48:129-137

Mistry J, Berardi A (2016) Bridging indigenous and scientific knowledge. Science 352:1274-1275

Mistry J, Bilbao BA, Berardi A (2016) Community owned solutions for fire management in tropical ecosystems: case studies from Indigenous communities of South America. Philosophical Transactions of the Royal Society B: Biological Sciences 371

Murphy BL (2011) From interdisciplinary to inter-epistemological approaches: Confronting the challenges of integrated climate change research. The Canadian Geographer / Le Géographe canadien 55:490-509.

Mustonen T (2013) Oral histories as a baseline of landscape restoration - Comanagement and watershed knowledge in Jukajoki River. Fennia 191:76-91 Nabhan GP (2000) Interspecific relationships affecting endangered species recognized by O’odham and Comcáac cultures. Ecological Applications 10: 1288-1295. Nagendra H (2007) Drivers of reforestation in human-dominated forests. Proceedings of the National Academy of Sciences of the United States of America 104:1521815223 
Nguyen TP, Luom TT, Parnell KE (2017) Mangrove allocation for coastal protection and livelihood improvement in Kien Giang province, Vietnam: Constraints and recommendations. Land Use Policy 63:401-407

Nielsen-Pincus M, Moseley C (2013) The Economic and Employment Impacts of Forest and Watershed Restoration. Restoration Ecology 21:207-214

NOAA (2017) URL http://response.restoration.noaa.gov/about/media/after-pollutionstrikes-restoring-lost-cultural-bond-between-tribes-and-environment.html

Papworth SK, Rist J, Coad L, Milner-Gulland EJ (2009) Evidence for shifting baseline syndrome in conservation. Conservation Letters 2: 93-100.

Paquette A, Hawryshyn J, Vyta Senikas A, Potvin C (2009) Enrichment Planting in Secondary Forests: a Promising Clean Development Mechanism to Increase Terrestrial Carbon Sinks. Ecology and Society 14

Paudyal K, Baral H, Burkhard B, Bhandari SP, Keenan RJ (2015) Participatory assessment and mapping of ecosystem services in a data-poor region: Case study of community-managed forests in central Nepal. Ecosystem Services 13:81-92

Pecl GT, Araújo MB, Bell JD, Blanchard J, Bonebrake TC, Chen I-C, Clark TD, Colwell RK, Danielsen F, Evengård B, Falconi L, Ferrier S, Frusher S, Garcia RA, Griffis RB, Hobday AJ, Janion-Scheepers C, Jarzyna MA, Jennings S, Lenoir J, Linnetved HI, Martin VY, Mccormack PC, Mcdonald J, Mitchell NJ, Mustonen T, Pandolfi JM, Pettorelli N, Popova E, Robinson SA, Scheffers BR, Shaw JD, Sorte CJB, Strugnell JM, Sunday JM, Tuanmu M-N, Vergés A, Villanueva C, Wernberg T, Wapstra E, Williams SE (2017) Biodiversity redistribution under climate change: Impacts on ecosystems and human wellbeing. Science 355 
Pellant M, Abbey B, Karl S (2004) Restoring the Great Basin Desert, U.S.A.:

Integrating Science, Management, and People. Environmental Monitoring and Assessment 99:169-179

Posey DA (1985) Indigenous management of tropical forest ecosystems: the case of the Kayapó indians of the Brazilian Amazon. Agroforestry Systems 3:139-158

Reynolds TW (2012) Institutional Determinants of Success Among Forestry-Based Carbon Sequestration Projects in Sub-Saharan Africa. World Development 40:542-554

Reyes-García, V. (2015) The Values of Traditional Ecological Knowledge. In MartinezAlier and R. Muradian (eds), Handbook of Ecological Economics. Edward Elgar. Chapter 12: 286-306

Robertson M, Nichols P, Horwitz P, Bradby K, Mackintosh D (2000) Environmental Narratives and the Need for Multiple Perspectives to Restore Degraded Landscapes in Australia. Ecosystem Health 6:119-133

Russell-Smith J, Yates CP, Edwards AC, Whitehead PJ, Murphy BP, Lawes MJ (2015)

Deriving Multiple Benefits from Carbon Market-Based Savanna Fire Management: An Australian Example. Plos One 10:e0143426

Salick J, Ghimire SK, Fang Z, Dema S, Konchar KM (2014) Himalayan Alpine Vegetation, Climate Change and Mitigation. Journal of Ethnobiology 34:276293

Sangha KK, Russell-Smith J (2017) Towards an Indigenous Ecosystem Services Valuation Framework: A North Australian Example. Conservation \& Society 15:255-269 
Selvam V, Ravichandran KK, Gnanappazham L, Navamuniyammal M (2003)

Assessment of Community-Based Restoration of Pichavaram Mangrove Wetland Using Remote Sensing Data. Current Science 85:794-798

Senos R, Lake FK, Turner N, Martinez D (2006) Traditional ecological knowledge and restoration practice. Pages 393-426 In: Apostol D, Sinclair M, (eds) Restoring the Pacific Northwest: the art and science of ecological restoration in Cascadia. Island Press, Washington, DC

Shaffer LJ (2010) Indigenous Fire Use to Manage Savanna Landscapes in Southern Mozambique. Fire Ecology 6:43-59

Singh RK, Kumar S, Jat HS, Singh A, Raju R, Sharma DK (2014) Adaptation in ricewheat based sodic agroecosystems: A case study on climate resilient farmers' practices. Indian Journal of Traditional Knowledge 13:377-389

Solomon D, Lehmann J, Fraser JA, Leach M, Amanor K, Frausin V, Kristiansen SM, Millimouno D, Fairhead J (2016) Indigenous African soil enrichment as a climate-smart sustainable agriculture alternative. Frontiers in Ecology and the Environment 14:71-76

Stenseke M (2009) Local participation in cultural landscape maintenance: Lessons from Sweden. Land Use Policy 26:214-223

Storm L, Shebitz D (2006) Evaluating the Purpose, Extent, and Ecological Restoration Applications of Indigenous Burning Practices in Southwestern Washington. Ecological Restoration 24:256-268

Thornton T, Deur D, Kitka Sr H (2015) Cultivation of Salmon and other Marine Resources on the Northwest Coast of North America. Human Ecology 43: 189199. 
Tobón W, Urquiza-Haas T, Koleff P, Schröter M, Ortega-Álvarez R, Campo J, LindigCisneros R, Sarukhán J, Bonn A (2017) Restoration planning to guide Aichi targets in a megadiverse country. Conservation Biology 31:1086-1097

Trauernicht C, Brook BW, Murphy BP, Williamson GJ, Bowman DMJS (2015) Local and global pyrogeographic evidence that indigenous fire management creates pyrodiversity. Ecology and Evolution 5:1908-1918

Trialfhianty TI, Suadi (2017) The role of the community in supporting coral reef restoration in Pemuteran, Bali, Indonesia. Journal of Coastal Conservation 21:873-882

Uprety Y, Asselin H, Bergeron Y, Doyon F, Boucher J-F (2012) Contribution of Traditional Knowledge to Ecological Restoration: Practices and Applications. Ecoscience 19:225-237

Varga A, Heim A, Demeter L, Molnár Z (2017) Rangers bridge the gap: integration of wood-pasture related traditional ecological knowledge into nature conservation. Pages 78-91 In: Roué M, Molnár Z, (eds) Knowing our Land and Resources: Indigenous and local knowledge of biodiversity and ecosystem services in Europe \& Central Asia. UNESCO, Paris

Wangpakapattanawong P, Kavinchan N, Vaidhayakarn C, Schmidt-Vogt D, Elliott S (2010) Fallow to forest: Applying indigenous and scientific knowledge of swidden cultivation to tropical forest restoration. Forest Ecology and Management 260:1399-1406

Wehi PM, Lord JM (2017) Importance of including cultural practices in ecological restoration. Conservation Biology 31:1109-1118 
Welch JR, Brondízio ES, Hetrick SS, Coimbra CEA, Jr. (2013) Indigenous Burning as Conservation Practice: Neotropical Savanna Recovery amid Agribusiness Deforestation in Central Brazil. Plos One 8:e81226

Xu W, Yin Y, Zhou S (2007) Social and economic impacts of carbon sequestration and land use change on peasant households in rural China: A case study of Liping, Guizhou Province. Journal of Environmental Management 85:736-745 